\title{
Muscular alterations in chronic obstructive pulmonary disaese and chronic heart failure at rest and during exercise
}

Citation for published version (APA):

Gosker, H. R., Uszko-Lencer, N. H. M. K., Wouters, E. F. M., van der Vusse, G. J., \& Schols, A. M. W. J. (2002). Muscular alterations in chronic obstructive pulmonary disaese and chronic heart failure at rest and during exercise. Progress in Respiratory Research, 32, 18-29. https://doi.org/10.1159/000062207

Document status and date:

Published: 01/01/2002

DOI:

10.1159/000062207

Document Version:

Publisher's PDF, also known as Version of record

\section{Document license:}

Taverne

Please check the document version of this publication:

- A submitted manuscript is the version of the article upon submission and before peer-review. There can be important differences between the submitted version and the official published version of record.

People interested in the research are advised to contact the author for the final version of the publication, or visit the DOI to the publisher's website.

- The final author version and the galley proof are versions of the publication after peer review.

- The final published version features the final layout of the paper including the volume, issue and page numbers.

Link to publication

\footnotetext{
General rights rights.

- You may freely distribute the URL identifying the publication in the public portal. please follow below link for the End User Agreement:

www.umlib.nl/taverne-license

Take down policy

If you believe that this document breaches copyright please contact us at:

repository@maastrichtuniversity.nl

providing details and we will investigate your claim.
}

Copyright and moral rights for the publications made accessible in the public portal are retained by the authors and/or other copyright owners and it is a condition of accessing publications that users recognise and abide by the legal requirements associated with these

- Users may download and print one copy of any publication from the public portal for the purpose of private study or research.

- You may not further distribute the material or use it for any profit-making activity or commercial gain

If the publication is distributed under the terms of Article $25 \mathrm{fa}$ of the Dutch Copyright Act, indicated by the "Taverne" license above, 


\title{
Muscular Alterations in Chronic Obstructive Pulmonary Disease and Chronic Heart Failure at Rest and during Exercise
}

\author{
Harry R. Gosker ${ }^{a}$ N icole H.M.K. U szko-Lencer ${ }^{b}$ Emiel F.M. W outers ${ }^{a}$ \\ Ger J. van der Vussec Annemie M.W .J. Scholsa \\ Departments of aPulmonology, ${ }^{b} \mathrm{C}$ ardiology and CPhysiology, Maastricht University, \\ Maastricht, The $\mathrm{N}$ etherlands
}

\begin{abstract}
Summary
Reduced skeletal muscle performance contributes to exercise intolerance in COPD and CHF patients, independent of the severity of local organ dysfunction. Striking similarities are observed in morphological and metabolic abnormalities in peripheral skeletal muscle between these two disorders, pointing towards a decreased oxidative capacity. Both diseases also share striking differences between peripheral muscles and the diaphragm, which may therefore require a different therapeutical approach. The following possible underlying factors of muscular alterations in COPD and CHF are discussed: hypoxia, oxidative stress, disuse, weight loss and altered substrate metabolism.
\end{abstract}

According to the definitions of the World Health Organization chronic diseases are not only characterized by their primary impairments, but also by the resulting disabilities or even handicaps [1]. Although the primary impairments in chronic obstructive pulmonary disease (COPD) and chronic heart faulure (CHF) clearly differ, there is a striking resemblance in the systemic consequences of these diseases and their effect on exercise capacity and health status. Skeletal muscle function in COPD and CHF has long been ignored as potential contributor by focusing on the ventilatory and cardiac limita- tions of exercise performance, respectively; but recent research has shown that skeletal muscle function is impaired in moderate to severe COPD and CHF and also is an important predictor of exercise limitation in both diseases [2-4]. Muscle function depends, among others, on perfusion, muscle mass, fibre composition and energy metabolism [5]. It can be inferred that alterations in one or more of these determinants play a role in reduced muscle performance. Indeed, both in COPD and in CHF such changes have been found and striking similarities between the two etiologically distinct disorders appear to be present.

In this paper we will first present an overview of clinical studies that have investigated impaired muscle function with special emphasis on muscle morphology and energy metabolism in COPD and CHF. In the second part of the paper, potential causes will be discussed including hypoxia, oxidative stress, disuse, weight loss and altered substrate metabolism.

\section{Muscular Alterations in COPD and CHF}

\section{Muscle Performance}

Muscle performance is largely characterized by strength and endurance. Strength is defined as the capacity of the muscle to develop maximal force and endurance as the capacity of the muscle to maintain a certain force in 
time, thus to resist fatigue. Loss of either one of these aspects results in muscle weakness and, hence, in impaired muscle performance. Numerous studies have now convincingly demonstrated that COPD and CHF are commonly associated with muscle weakness [6-8]. Hamilton et al. [3] found significantly reduced strengths of both peripheral and respiratory muscles in patients suffering from respiratory failure, heart failure, or a combination of both as compared to healthy subjects. However, strength and endurance seem not to be affected in the same way in respiratory and peripheral muscles. This is illustrated by the poor correlation between the strengths of both muscle groups in both disorders [7, 8], compared to a much stronger correlation in healthy subjects [9]. It implies that the strength component of muscle weakness is affected differently in peripheral and respiratory muscles. In healthy subjects, as well as in patients, exercise limiting symptoms are the sense of leg effort (exertional discomfort) and/or breathlessness (exertional dyspnoea) $[10,11]$. Despite correlations between peripheral muscle strength and performance in COPD and CHF [7, 10], reduced endurance ( $\sim$ fatigue) seems to be the dominating limiting factor in peripheral muscles in these patients, since the sense of leg effort was one of the main reasons to stop exercise [3, 11-13]. Recently, it has been shown that early lactic acidosis occurs in COPD during exercise [14] and that this is largely the result of lactate release from the lower exercising limb [15]. In CHF reports lactate release is thought to be a result of decreased blood flow to the peripheral muscles. Muscle acidosis is a contributing factor to muscle fatigue [16].

Fatigue probably is not the main limiting factor in respiratory muscle function. Morrison et al. [17] found that COPD subjects have decreased respiratory muscle strength and endurance. Fatigue of the respiratory muscle may indeed occur during exercise, but it is not certain whether this is an independent determinant of exercise capacity $[12,18,19]$. In addition, it is unlikely that the respiratory muscles from exercising COPD patients contribute to the lactate response mentioned earlier [20]. It also should be emphasized that the respiratory muscles must operate against the mechanical airway impedances in this specific disorder [21], for which the force component of respiratory muscle function is most likely of great importance. For CHF it was found that respiratory muscle strength and not respiratory muscle fatigability correlated with the degree of dyspnoea [22]. It thus seems that strength is the limiting aspect of muscle performance in the respiratory muscle, whereas endurance limitation dominates in peripheral muscles. However, more detailed studies are required to clarify the individual roles of strength and endurance limitation in peripheral and respiratory muscles in COPD and CHF.

\section{Muscle Morphology}

In both CHF [10, 23] and COPD [2, 24-27] marked loss of muscle mass or decline in cross-sectional area is observed. This muscle wasting plays an important role in the loss of exercise tolerance in these patients. Morphological alterations may also be related to muscle function impairment, although direct relationship with exercise performance have not (yet) been shown. Some histological information is available on abnormalities in skeletal muscle in CHF but hardly any on COPD. Recently, reduced fibre cross-sectional area has been demonstrated in the vastus lateralis of COPD [28] and CHF [29]. Gertz et al. [30] found no sings of increased fibrosis or other alterations in intercostal muscles from patients with respiratory failure, whereas endomyosal fibrosis has been found in skeletal muscle of a limited number of $\mathrm{CHF}$ patients [31]. Increased acid phosphatase activity, a lysosomal enzyme contributing to protein degradation, has been found in the quadriceps of some patients with $\mathrm{CHF}$ [32] or respiratory failure [27]. Increased lipid deposits have been found in the quadriceps, biceps and deltoids of some patients with CHF [27, 32]. Very contradicting results have been obtained with respect to capillary density in peripheral skeletal muscle in CHF. A normal capillary density has been found [27], which is in confirmation with other studies where both a reduced capillary/fibre ratio and atrophy resulted in an unchanged capillary density [32]. An unaltered capillary/fibre ratio has also been reported; however, capillary density increased due to fibre atrophy [34]. In contrast, reduced capillary density in combination with a reduced capillary/fibre ratio has been shown in CHF patients [35] and even in heart transplantation recipients [36]. Thus, there is an overall tendency for a reduced capillary/fibre ratio, but depending on the degree of atrophy the capillary density may even be increased. This has recently been confirmed for COPD [25]. In a few studies morphometry of mitochondria has been performed using electron microscopy, showing that mitochondrial volume densities in skeletal muscle are lower in CHF patients compared to control subjects [35, 37], which was still the case 10 months after heart transplantation [36]. Histochemical alterations reflecting mitochondrial abnormalities have also been reported in biceps muscle biopsies of COPD patients [27]. These results suggest that oxidative capacity in peripheral skeletal muscles may be altered. 


\section{Muscle Fibre Type Distribution}

The most remarkable muscle alteration in COPD and $\mathrm{CHF}$ is a relative shift in fibre composition which seems to occur in opposite direction in peripheral and respiratory muscle. Fibre typing is mainly performed histochemically, based on the differences in myosin ATPase activities, or immunocytochemically [38]. Adult mammalian skeletal muscle contains four myosin heavy chain (MyHC) isoforms, namely type I, IIa, IIb and IIx [39]. In most older studies fibre typing is limited to determining fibre types I, IIa and IIb. Furthermore, human fibres formerly identified as being IIb with myosin ATPase staining are probably IIx fibres [40]. Therefore the notation $\mathrm{IIb} / \mathrm{x}$ will be used in the subsequent text. Fibre type I has a slow-twitch and develops a relative small tension, but since it depends mainly on aerobic metabolism it is fatigue resistant. In contrast, fibre type IIb/x has a fasttwitch and develops large tensions, but it is susceptible for fatigue, since in type $\mathrm{IIb} / \mathrm{x}$ fibres energy conversion is based on anaerobic, glycolytic metabolism. Fibre type II has intermediate properties in that it also has a fast twitch, develops a moderate tension, is relatively resistant to fatigue and is apt to work under both aerobic and anaerobic conditions $[5,38]$. A decrease of the percentage of type I fibres and a corresponding increase in type II (mainly type IIb/x) fibres compared to normal subjects has been reported for COPD [25, 41, 42] and for CHF [32-35, 43] in limb muscles. In addition, recently we demonstrated increased proportions of I/IIa and IIa/IIx hybrid fibres in COPD [44]. These fibres may represent transformation intermediates in the I $\rightarrow$ IIx shift. In contrast to peripheral muscles, a shift from type IIb/x to type I fibres has been reported in the diaphragm in both COPD and CHF patients. Despite some variation in the results obtained till now, there is most likely a $\mathrm{I} \rightarrow \mathrm{IIb} / \mathrm{x}$ shift in peripheral muscles and a IIb/ $x \rightarrow I$ shift in the respiratory muscle. It is feasible that these shifts have functional consequences in the affected muscles, since the distinct fibre types have different contractile properties with respect to twitch and fatigue resistance. Therefore, in COPD and $\mathrm{CHF}$, a I $\rightarrow \mathrm{IIb} / \mathrm{x}$ shift accompanied by more glycolytic and less oxidative capacity in peripheral muscles implies loss of fatigue resistance. This change might contribute to the observed loss of exercise tolerance, since peripheral muscle fatigue is the main limiting factor in these patients. This is confirmed by a study in which a faster twitch response in combination with less resistance to fatigue was observed in leg muscles of CHF patients [45]. Accordingly, a IIb/ $\mathrm{x} \rightarrow \mathrm{I}$ shift towards more oxidative metabolism in the respiratory muscle implies a shift towards a more fatique-resistant, but less strength adapted muscle. This too is in line with our notion that strength and not fatigue seems to be the main limiting factor for respiratory muscle function.

\section{Muscle Energy Metabolism}

Considerable amounts of data are available on skeletal muscle metabolism in CHF and COPD, partly because of the applicability of ${ }^{31} \mathrm{P}$-nuclear magnetic resonance $\left({ }^{31} \mathrm{P}\right.$ NMR) which has enabled a direct and non-invasive assessment of tissue levels of high-energy phosphates and $\mathrm{pH}$. High levels of adenosine triphosphate (ATP), creatine phosphate $(\mathrm{CrP})$ and nicotinamide adenine dinucleotide in the reduced form (NADH) reflect a high energy state, whereas elevated levels of adenosine diphosphate (ADP), adenosine monophosphate (AMP), inorganic phosphate $(\mathrm{Pi})$ and oxidized nicotinamide adenine dinucleotide $\left(\mathrm{NAD}^{+}\right)$commonly reflect a low energy state. Lactate and glycogen levels are often measured, but it must be noted that low levels may reflect either increased clearance or reduced formation and vice versa for high levels. Although activities of enzymes involved in muscle energy metabolism do not reflect the physiological situation since only maximal activities are obtained under the optimal circumstances of in vitro measurements, they do provide an indication for adaptations in expressions of proteins involved in metabolic pathways. Typical oxidative enzymes are citrate synthase (CS), succinate dehydrogenase (SDH) and $\beta$-hydroxyacyl-CoA dehydrogenase (HAD). Typical glycolytic enzymes are hexokinase (HK), phosphofructokinase (PFK) and lactate dehydrogenase $(\mathrm{LDH})$, the latter catalysing the last step of anaerobic glycolysis. Measurements of substrate and cofactor levels in peripheral skeletal muscle of COPD and CHF patients indicate impaired energy metabolism (see table 3). Most striking are the observed reduced levels of the high-energy phosphates in rest. Pouw et al. [46] observed higher Pi/ Crp and ADP/ATP ratios associated with slightly, but statistically significantly elevated inosine monophosphate (IMP) levels. The latter may be due to increased degradation of accumulating AMP by deamination, which probably reflects reduced aerobic capacity [47]. The situation becomes even worse during exercise: greater increase of the $\mathrm{Pi} / \mathrm{CrP}$ ratio and a faster drop in $\mathrm{pH}$ were found in the calf muscle of COPD patients [48, 49] and of CHF patients $[34,50,51]$ performing exercise. Similar results have been obtained for the forearm muscle $[51,52]$ (table 1). In addition, a slower recovery of $\mathrm{CrP}$ was observed 
Table1. Changes in muscle energy metabolism during exercise

\begin{tabular}{|c|c|c|c|c|c|c|c|c|}
\hline \multirow[t]{2}{*}{ Disorder } & \multirow[t]{2}{*}{ Ref. } & \multirow[t]{2}{*}{ Muscle } & \multicolumn{6}{|c|}{ Variables of NMR spectroscopy } \\
\hline & & & $\mathrm{PCr}$ & $\mathrm{Pi} / \mathrm{PCr}$ & $\mathrm{PCr} /(\mathrm{PCr}+\mathrm{Pi})$ & ATP & relATP & $\mathrm{pH}$ \\
\hline \multirow{6}{*}{ COPD } & 54 & calf & $\downarrow$ & & & & & $\downarrow$ \\
\hline & 53 & calf & & $\uparrow$ & & $=$ & & $\downarrow$ \\
\hline & 55 & calf & & $\uparrow$ & & & $\downarrow$ & $\downarrow$ \\
\hline & 56 & quadriceps & & $=$ & & & & $=$ \\
\hline & 57 & forearm & & & $\downarrow N S$ & & & $=$ \\
\hline & 58 & forearm & & $\uparrow$ & $\downarrow$ & & $\uparrow$ & $\downarrow$ \\
\hline \multirow[t]{6}{*}{$\mathrm{CHF}$} & 60 & calf* & $=$ & $=$ & $=$ & $=$ & $=$ & $=$ \\
\hline & 60 & calf** & & $\uparrow$ & & $=$ & $\uparrow$ & $\downarrow$ \\
\hline & 59 & calf & & & $=$ & & & $\downarrow$ \\
\hline & 34 & calf & & & & & & $\downarrow$ \\
\hline & 61 & calf & & & & & & $\downarrow$ \\
\hline & 57 & forearm & & $\downarrow \mathrm{NS}$ & & & & $=$ \\
\hline
\end{tabular}

$\mathrm{Pi}=$ Inorganic phosphate $\mathrm{PCr}=$ phosphocreatine; $\mathrm{ATP}=$ adenosime triphosphate; relATP $=$ ATP corrected for $\mathrm{Pi} / \mathrm{PCr} ; \uparrow$ significantly increased compared to controls; $\downarrow$ significantly decreased compared to controls; = means in patients not significantly different from controls; * compared to sedentary controls; ** compared to trained controls.

Table 2. Muscle energy metabolism in the recovery phase after exercise

\begin{tabular}{|c|c|c|c|c|c|c|c|c|}
\hline \multirow[t]{2}{*}{ Disorder } & \multirow[t]{2}{*}{ Ref. } & \multirow[t]{2}{*}{ Muscle } & \multicolumn{6}{|c|}{ Variables of NMR spectroscopy } \\
\hline & & & $\mathrm{PCr} / \mathrm{RT}^{1 / 2}$ & $\mathrm{PCr} /(\mathrm{PCr}+\mathrm{Pi}) / \mathrm{RT}^{1 / 2} 2$ & $\mathrm{Pi} / \mathrm{PCr}$ & $\mathrm{RT}^{1} / 2$ & $\mathrm{pH}$ & $\mathrm{pH} / \mathrm{RT}^{1 / 2}$ \\
\hline \multirow{5}{*}{ COPD } & 53 & calf & $\uparrow$ & & & & & \\
\hline & 54 & calf & $=$ & & & & & \\
\hline & 55 & calf & $\uparrow$ & & & & & \\
\hline & 58 & forearm & & $\uparrow$ & & & & $\uparrow$ \\
\hline & 57 & forearm & & & $\uparrow$ & & $\downarrow$ & $\uparrow$ \\
\hline \multirow[t]{4}{*}{$\mathrm{CHF}$} & 60 & calf* & & & & $=$ & & \\
\hline & 60 & calf** & & & & $=$ & & \\
\hline & 61 & calf & $\uparrow$ & & & & & \\
\hline & 57 & forearm & $\uparrow$ & & $\downarrow$ & $\uparrow$ & $\downarrow \mathrm{NS}$ & \\
\hline
\end{tabular}

$\mathrm{Pi}=$ Inorganic phosphate $\mathrm{PCr}=$ phosphocreatine; $\mathrm{RT}^{1} \frac{1}{2}=$ recovery halftime; $\uparrow$ significantly increased compared to controls; $\downarrow$ significantly decreased compared to controls; = means in patients not significantly different from controls; * compared to sedentary controls; ** compared to trained controls.

after exercise [34, 49-52]. COPD patients also show a prolonged half-time $\left(\mathrm{RT}^{1 / 2}\right)$ for $\mathrm{pH}[53-55,57,58]$ (table 2). These results suggest that rephosphorylation of high-energy phosphates is less efficient in these patients both during and after muscular exercise. In CHF patients, Chati et al. [60] compared NMR spectra of calf muscles during exercise with sedentary and trained controls. They found no difference between patients and sedentary controls and concluded deconditioning being an important factor for the abnormalities. In addition, glycogen contents in patients tend to be lower, whereas lactate levels are higher (table 3). It thus seems that anaerobic energy metabolism is enhanced and since this process yields far less ATP compared to complete oxidative degradation of 
Table 3. Muscle metabolite concentrations in COPD and CHF

\begin{tabular}{lllll}
\hline Metabolite & Muscle & Disorder & Direction References \\
\hline CrP & QF & COPD & $\downarrow$ & $30,124,125,126^{*}$ \\
& QF & CHF & $\downarrow$ & $127,128^{*}$ \\
\hline ATP & QF & COPD & $\downarrow$ & $30,124,125,126^{*}$ \\
& QF & CHF & $\downarrow$ & $127,128^{*}$ \\
\hline IMP & TA & COPD & $\uparrow$ & 46 \\
\hline Glycogen & QF & CHF & $\downarrow$ & $32,127,128$ \\
& QF & COPD & $\downarrow$ & $124,125^{*}$ \\
\hline Lactate & QF & COPD & $\uparrow$ & 30,126 \\
& QF & CHF & $\uparrow$ & 129 \\
\hline Pyruvate & QF & CHF & $\uparrow$ & 32 \\
& QF & COPD & $\uparrow$ & 14
\end{tabular}

$\mathrm{ATP}=$ Adenosine triphosphate $\mathrm{CrP}=$ creatine phosphate IMP = inosine monophosphate; $\mathrm{QF}=$ quadriceps femoris; $\mathrm{TA}=$ tibialis anterior; * nearly reached significance.

glucose this could explain the reduced high-energy phosphate levels.

Analysis of enzyme activities too suggest an overall increase of glycolytic and an overall decrease of oxidative activities in peripheral muscles of both COPD and CHF patients (table 4). Since these enzyme activities depend largely on the fibre type [62], it is likely that this shift in activities is related to the shift in fibre distribution mentioned above. Whether enzyme activities adapt to the fibre type redistribution or the other way around remains unclear. Due to technical difficulties with ${ }^{31} \mathrm{P}-\mathrm{NMR}$ and muscle biopsies of the diaphragm and accessory respiratory muscles, very little is known about energy metabolism in these muscles. However, the observed alterations for enzyme activities (table 4) are in confirmation with the morphological data, in that oxidative enzyme activities are reduced and glycolytic enzyme activities are increased. As in peripheral muscles, this shift probably results from the shift in fibre type distribution.

\section{Possible Underlying Factors}

\section{Hypoxia}

In COPD and CHF oxygen delivery to peripheral and respiratory muscles may be insufficient, caused by either hypoxemia and/or reduced blood supply. In both cases
Table 4. Muscle enzyme activities

\begin{tabular}{lllll}
\hline Enzyme & Muscle & Disorder & Direction & References \\
\hline CS & QF & COPD & $\downarrow$ & 130,131 \\
& QF & CHF & $\downarrow$ & $32,34,129,132$ \\
& DIA & CHF & $\uparrow$ & 133 \\
\hline HAD & QF & COPD & $\downarrow$ & 130,131 \\
& QF & CHF & $\downarrow$ & $32,34,129,132$ \\
& DIA & CHF & $\uparrow$ & 133 \\
\hline SDH & QF & COPD & $\downarrow$ & 131 \\
& QF & CHF & $\downarrow$ & 32,132 \\
\hline LDH & QF & COPD & $\uparrow$ & 131 \\
& QF & CHF & $\uparrow$ & $129 *$ \\
& DIA & CHF & $\downarrow$ & 133 \\
& DIA & COPD & $\downarrow$ & 134 \\
\hline HK & QF & CHF & $\downarrow$ & 132 \\
& DIA & COPD & $\downarrow$ & 134 \\
\hline PFK & QF & COPD & $\uparrow$ & 131 \\
\hline
\end{tabular}

$\mathrm{CS}=$ Citrate synthase HAD $=\beta$-hydroxyacyl-CoA dehydrogenase; $\mathrm{SDH}=$ succinate dehydrogenase; $\mathrm{HK}=$ hexokinase; $\mathrm{PFK}=$ phosphofructokinase; $\mathrm{LDH}=$ lactate dehydrogenase; $\mathrm{QF}=$ quadriceps femoris; DIA = diaphragm.

muscle tissue may become hypoxic and this could lead to the adaptive changes in skeletal muscle as those described above. In this respect relevant information is now available from mountaineering expeditions (lasting at least 6 weeks above $5,000 \mathrm{~m}$ ), since oxygen is limited at this altitude. Under these conditions reductions in mitochondrial volume densities, in oxidative enzyme activities and in cross sectional areas of muscle fibers were found in the quadriceps $[63,64]$. But such expeditions are accompanied by strenuous physical activity, which also causes muscular adaptations other than those caused by hypoxia. In fact, the effect of training in combination with hypoxia may even cause a shift towards more oxidative metabolism [65].

More information about the effect of hypoxia on muscle has been obtained from animal studies. Several of these studies have shown that hypoxia can indeed lead to the muscular alterations as described for limb muscles in COPD and CHF: (1) Reduced fibre diameters in combination with unaffected numbers of capillaries, resulting in increased capillary densities, have been reported in rats exposed to hypoxia [66, 67]. (2) Some studies revealed that hypoxia depresses protein synthesis $[68,69]$, includ- 
ing in muscle tissue [68]. Chronic hypoxia inhibits the normal conversion of type IIa to type I fibres in growing rats, resulting in a predominating proportion of type IIa fibres compared to control rats [70]. So hypoxia does not directly cause a type I $\rightarrow$ II fibre shift, but causes an abnormal fibre type distribution from alterations in muscular development. It is feasible that in COPD and CHF a similar mechanism underlies the abnormal fibre type distribution in the regeneration of damaged muscle or the adaptation of muscles to consequences of the disease. (3) There is evidence that hypoxia causes a shift towards glycolytic metabolism, resulting in an increased lactateto-pyruvate ratio $[71,72]$ and reduced malate dehydrogenase, a citric acid enzyme [73]. (4) Hypoxia causes stimulation of glucose transport [74] and increased levels of membrane-associated glucose transporters (GLUT1 and GLUT4) in rat muscle [75].

It should be noted, however, that in COPD and CHF this reduction of oxidative capacity does not occur in the diaphragm. It is feasible that hypoxia causes an endurance training effect in the diaphragm due to increased ventilation, which overrides its direct effect ultimately resulting in a shift towards more aerobic metabolism.

\section{Oxidative Stress}

Oxidative stress may be another factor contributing via reactive oxygen species to muscle damage. In both COPD and CHF increased plasma levels of lipid peroxidation products have been found [76, 77]. Sources of free oxygen radicals are: (1) Mitochondria, since $2-5 \%$ of the total oxygen consumed is not fully reduced in the electron transport chain and may leak away as superoxide radicals $[78,79]$. (2) Immune cells activated during inflammation [80]. Monocytes and macrophages produce cytokine tumor necrosis factor- $\alpha(\mathrm{TNF} \alpha)$ which may in turn induce oxidative stress in myocytes [81]. Elevated TNF $\alpha$ blood levels have indeed been found in both COPD $[82,83]$ and CHF $[84,85]$, in particular in those patients characterized by weight loss and/or muscle wasting. (3) Xanthine oxidase, in case of a low energy state, is involved in the degradation of AMP [79]. The above-mentioned elevated IMP levels in COPD [46] indeed suggest enhanced AMP breakdown. Susceptibility to these free radicals largely depends on the antioxidant status of tissue [79]. The main antioxidant scavengers and enzymes are, amongst others, reduced glutathione, vitamin E (in cell membranes), superoxide dismutase (SOD), glutathione peroxidase and catalase $[79,86]$. Long-term training stimulates the defense system against oxygen free radicals $[78,79,86]$ and the disuse of muscles thus may lack this antioxidant stim- ulating trigger resulting in a reduced antioxidant status. Chronic hypoxia probably acts in the same way, since limitations of oxygen supply are indeed found to be associated with reductions in SOD activity in mammalian tissues like brain, lungs and heart, although this change was not found in skeletal muscle tissue [87, 88]. In addition, in myocytes (obtained from chronic hypoxic human myocardium) cultured at low oxygen tension, antioxidant enzyme activities were lower than in myocytes cultured at a higher oxygen tension, illustrating the direct modulatory effect of oxygen [89]. In vivo and in vitro hypoxia-reoxygenation studies revealed that oxygen oversupply following a period of oxygen shortage may give rise to free radical formation in myocytes [87, 90]. Accordingly, in COPD and CHF chronic hypoxia may result in a reduced antioxidant status and occasional bouts of exercise may cause a boost of free radicals exceeding the capacity of the defence system [78]. It is also feasible that the reduced oxidative capacity in the patients itself leads to enhanced oxidative stress, since the sudden oversupply of oxygen during exercise is inefficiently metabolised.

Reactive oxygen species are well capable of damaging lipids and proteins [78, 79, 86, 91]. Radicals that react with fatty acyl moieties in membrane phospholipids cause a chain reaction of peroxidations increasing the membrane permeability [91]. Maintenance of membrane integrity is crucial for: (1) Adequate functioning of the respiratory chain, since the driving force for oxidative ATP synthesis is the electrochemical proton gradient over the inner membrane of the mitochondrion, which is generated during the electron transfer from NADH to oxygen [92]. (2) To prevent intracellular calcium overload, caused by damaged sarcoplasmatic reticulum membrane, in combination with impaired activity of calcium ATPases, which accompanies oxidative stress in animal myocytes [78, 87, 90, 93], and may further uncouple respiration from ATP production through extensive depolarisation of the inner membrane [94].

Protein oxidation by oxygen free radicals leads to formation of carbonyl groups on amino acid residues, which may modify the structure and/or chemical properties of the proteins affected [95]. These alterations may cause decline in function or even complete protein unfolding. The latter gives rise to enhanced susceptibility to proteinases. These modified proteins may also be recognized as foreign substances and, hence, be attacked by the immune system. Whether radical induced protein damage plays a role in the abnormalities in muscles of COPD and CHF patients is unclear. It has been shown in animal studies that in vivo induced oxidative stress caused myofibrillar 
muscle protein modification and that these proteins were rapidly degraded by proteases [96]. Thus theoretically, muscle atrophy can be enhanced by radical induced protein damage. Indeed, it has been shown that a calcium overload is involved in muscle atrophy [97] and that vitamin E deficiency facilitates muscle wasting and necrosis [98], both probably mediated by oxidative damage to proteins. Also, in human skeletal muscle it has been shown that mitochondria and mitochondrial proteins were more susceptible to oxidative damage compared to other subcellular components [99], which suggests that protein damage may cause impaired oxidative metabolism.

As opposed to necrosis, which is the result of exogenous damage as described above, apoptosis of muscle cells is an active process of cell death, which recently also has been associated with oxidative stress [100]. In this study the exposure of rat myoblasts to nitric oxide or hydrogen peroxidase led to apoptotic cell death. Since these chemical stimuli are also released by immune cells, it cannot be excluded that apoptosis underlies muscle wasting during inflammation.

\section{Disuse}

Disuse (low level of physical exercise because of their disease) of skeletal muscle is also a factor that most likely contributes to the observed muscle alterations in COPD and CHF. This results in: (1) Muscle weakness, due to reduced motor neuron activity and muscle wasting [38, 101]. (2) Relative reduction in the percentage of type I fibres and an increase in the percentage of type $\mathrm{IIb} / \mathrm{x}$ fibres [38, 102]. (3) A decline in activity of enzymes involved in oxidative energy conversion, which occurs both in type I and type II fibres [102], suggesting that it can occur even without any change in fibre composition. (4) A negative effect on the antioxidant status enhances the risk of oxidative damage. As mentioned above, the diaphragm is probably not disused and a kind of endurance training effect may even occur. This may not only be true for COPD, but for CHF as well, since especially in severe $\mathrm{CHF}$ dyspnoea and elevated ventilation occur already at rest $[13,103]$.

\section{Weight Loss and Altered Substrate Metabolism}

Weight loss commonly occurs in COPD $[104,105]$ and in CHF $[23,106]$ and is an independent determinant of mortality [107, 108]. In both disorders in particular loss of FFM is an important determinant for exercise capacity [2, 24, 109]. Determination of body composition, and not only weight, with respect to nutritional depletion is very important since at least in COPD different patterns of weight loss can be distinguished: predominant loss of fat mass, predominant loss of fat-free mass or a combination of both. Predominant loss of fat mass involves an impaired balance between energy requirement and energy intake. Although limited information is available in CHF patients, a negative energy balance commonly occurs in COPD as a result of either a decreased dietary intake, elevated energy requirements or a combination of both. Total daily energy metabolism (TDE) can be divided in 3 components: resting energy expenditure (REE), measured under fasting conditions in the early morning, diet induced thermogenesis (DIT) and physical activity induced (PAI) thermogenesis. REE comprises the major part of TDE, DIT on average only $10-15 \%$ and PAI can be highly variable. While in many chronic wasting diseases, REE is increased, probably related to an enhanced systemic inflammation, TDE is not different from healthy control subjects due to a compensatory decrease in daily activities. In contrast, TDE in COPD was found to be increased as a result of an increased PAI [110]. It is yet unclear to what extent an increased PAI is related to a decreased mechanical or a decreased metabolic efficiency and what the contributing role is of peripheral skeletal muscles versus the diaphragm.

In a situation of semistarvation, either primarily due to increased energy requirements or due to decreased dietary intake, loss of both fat mass and fat-free mass occurs, but the loss of fat-free mass is relatively preserved. Therefore, intrinsic muscle abnormalities besides loss of muscle mass must account for impaired muscle performance. Studies on muscle function and histology in anorexia nervosa patients provide strong data on the effect of undernutrition per se on muscles. Muscle performance is markedly impaired in these patients [111-113] and is associated with weight loss, loss of muscle mass and fibre atrophy (particularly of type II fibres) $[114,115]$. We recently demonstrated selective fibre type IIx atrophy in COPD patients associated with a reduced fat-free mass, suggesting a role for undernutrition in this disease too [44]. Data from animal studies confirm these effects of undernutrition. Decreased activities of enzymes involved in glycolytic and mitochondrial pathways have been reported from muscle biopsies of patients with anorexia nervosa [99, 111], with glycolytic capacity being affected the most [111]. The contribution of nutritional depletion to a shift from oxidative to glycolytic metabolism in COPD and CHF patients needs further investigation.

Disproportionate loss of fat-free mass often referred as cachexia, involves an impaired balance between protein anabolism and catabolism. Protein depletion itself may 
impair skeletal muscle performance as reflected by reduced maximum voluntary handgrip strength, reduced respiratory muscle strength and an increased fatigability of in vivo electrically stimulated adductor pollicis muscle [116]. Predominant loss of fat-free mass with relative preservation of fat mass also points towards alterations in substrate metabolism. Partly independent of pulmonary or cardiac cachexia, other disease characteristics like hypoxia or hypercapnia may alter substrate metabolism. Insulin has a central role in substrate metabolism. Hyperinsulinemia has been described in COPD and insulin resistance commonly occurs in $\mathrm{CHF}$. While nearly no data are available regarding carbohydrate and fat metabolism in fasting, fed or stressed states, protein metabolism has been subject of recent investigations in COPD. In nondepleted COPD patients, an increased whole-body protein turnover was observed at rest and specifically in emphysema a suppressed whole body protein turnover was observed during and immediately after exercise [118, 119]. Whole-body protein turnover, however, does not necessarily reflect muscle protein turnover. A study in underweight patients with emphysema reported a reduced muscle protein synthesis [117], while protein degradation was not increased $[119,120]$. It is feasible that amino acids are required in other processes than muscular protein synthesis, such as gluconeogenesis. Besides, recent data also showed intrinsic alterations in the amino acid profile of peripheral skeletal muscles. Most consistent results were found with respect to the amino acid glutamate (GLU). Intracellular GLU has various important functions, as it plays an important role in preserving highenergy phosphates in muscle through different metabolic mechanisms. GLU concentration is high in the free amino acid pool of human skeletal muscle. Intracellular GLU is known as an important precursor for the antioxidant glutathione (GSH) and glutamine synthesis in the muscle. Muscle GLU is indeed highly associated with muscle GSH, and patients with emphysema suffer from decreased muscular GLU and GSH levels [122]. Studies have shown that in healthy human muscle, the GLU pool functions to generate tricarboxylic acid (TCA) intermediates during the first minutes of exercise, which is achieved via the alanine aminotransferase reaction (pyruvate + GLU $\rightarrow$ alanine $+\alpha$-ketoglutarate) at the cost of GLU. Moreover, this reaction can shunt the pyruvate accumulated during exercise towards alanine instead of lactate, suggesting a possible role of the intracellular GLU level in the lactate response to exercise. In line with this hypothesis early lactic acidosis during exercise in patients with COPD was indeed associated with a reduction in muscle GLU [14]. Not only at rest, but also during $20 \mathrm{~min}$ of submaximal constant cycle exercise a different response in amino acid status was found in skeletal muscle and plasma of COPD patients as compared with healthy age-matched controls [123]. A significant reduction of most muscle amino acids was present postexercise, whereas several plasma amino acids were increased, suggesting an enhanced amino acid release from muscle in COPD during exercise. The increase in plasma alanine and glutamine was even higher postexercise, suggesting enhanced nitrogen efflux. Although investigation of substrate metabolism in COPD and CHF is still in its infancy, the available studies clearly point towards therapeutic perspective, not only in cachectic patients, but also as anabolic stimulus to enhance muscle and exercise performance. In frail elderly it has indeed been observed that oral amino acid intake stimulates the transport of amino acids into muscle, and that there is a direct link between amino acid transport and protein synthesis when ingested before exercise or some time after exercise.

\section{Conclusions}

This review underscores that reduced skeletal muscle performance markedly contributes to exercise intolerance in COPD and CHF patients. Morphologic and metabolic abnormalities occur in the skeletal muscles of these patients which, in both disorders, probably are determined by the same set of contributing factors. Both diseases also share striking differences between peripheral muscles and the diaphragm which, therefore, may require a different therapeutical approach. 


\section{References}

1 Wood PH: Appreciating the consequences of disease: The international classification of impairments, disabilities, and handicaps. WHO Chron 1980;34:376-380.

2 Schols AM, Mostert R, Soeters PB, Wouters EF: Body composition and exercise performance in patients with chronic obstructive pulmonary disease. Thorax 1991;46:695-699.

3 Hamilton AL, Killian KJ, Summers E, Jones NL: Muscle strength, symptom intensity, and exercise capacity in patients with cardiorespiratory disorders. Am J Respir Crit Care Med 1995; 152:2021-2031.

4 Steele IC, Moore A, Nugent AM, Riley MS, Campbell NPS, Nicholls DP: Non-invasive measurement of cardiac output and ventricular ejection fractions in chronic cardiac failure: Relationship to impaired exercise tolerance. Clin Sci 1997;93:195-203.

5 Armstrong RB: Muscle fiber recruitment patterns and their metabolic correlates; in Horton HS, Terjung RL (eds): Exercise, Nutrition, and Energy Metabolism. New York, Macmillan, 1988, pp 9-26.

6 Bernard S, LeBlanc P, Whittom F, Carrier G, Jobin J, Belleau R, Maltais F: Peripheral muscle weakness in patients with chronic obstructive pulmonary disease. Am J Respir Crit Care Med 1998;158:629-634.

7 Gosselink R, Troosters T, Decramer M: Peripheral muscle weakness contributes to exercise limitation in COPD. Am J Respir Crit Care Med 1996;153:976-980.

8 Chua TP, Anker SD, Harrington D, Coats AJ: Inspiratory muscle strength is a determinant of maximum oxygen consumption in chronic heart failure. Br Heart J 1995;74:381-385.

9 Lands LC, Heigenhauser GJ, Jones NL: Respiratory and peripheral muscle function in cystic fibrosis. Am Rev Respir Dis 1993;147:865869.

10 Harrington D, Anker SD, Chua TP, Webb Peploe KM, Ponikowski PP, Poole Wilson PA, Coats AJ: Skeletal muscle function and its relation to exercise tolerance in chronic heart failure. J Am Coll Cardiol 1997;30:1758-1764.

11 Killian KJ, Leblanc P, Martin DH, Summers E, Jones NL, Campbell EJ: Exercise capacity and ventilatory, circulatory, and symptom limitation in patients with chronic airflow limitation. Am Rev Respir Dis 1992;146:935-940.

12 Belman MJ: Exercise in patients with chronic obstructive pulmonary disease. Thorax 1993; 48:936-946.

13 Myers J, Salleh A, Buchanan N, Smith D, Neutel J, Bowes E, Froelicher VF: Ventilatory mechanisms of exercise intolerance in chronic heart failure. Am Heart J 1992;124:710-719.

14 Engelen MPKJ, Schols AMWJ, Does JD, Wouters EFM: Exercise induced lactate increase in relation to physical activity level and peripheral muscle substrates in COPD. Am J Respir Crit Care Med 1999;159:A475.
15 Maltais F, Jobin J, Sullivan MJ, Bernard S, Whittom F, Killian KJ, Desmeules M, Bélanger M, LeBlanc P: Metabolic and hemodynamic responses of lower limb during exercise in patients with COPD. J Appl Physiol 1999; 84:1573-1580.

16 Mainwood GW, Renaud JM: The effect of acid-base balance on fatigue of skeletal muscle. Can J Physiol Pharmacol 1985;63:403-416.

17 Morrison NJ, Richardson J, Dunn L, Pardy RL: Respiratory muscle performance in normal elderly subjects and patients with COPD. Chest 1989;95:90-94.

18 Decramer M, Aubier M: The respiratory muscles: Cellular and molecular physiology. Eur Respir J 1997;10:1943-1945.

19 Fitting JW: Respiratory muscle fatigue limiting physical exercise? Eur Respir J 1991;4:103108.

20 Engelen MP, Casaburi R, Rucker R, Carithers $\mathrm{E}$ : Contribution of the respiratory muscles to the lactic acidosis of heavy exercise in COPD. Chest 1995;108:1246-1251.

21 O'Donnell DE, Webb KA: Exertional breathlessness in patients with chronic airflow limitation: The role of lung hyperinflation. Am Rev Respir Dis 1993;148:1351-1357.

22 Mancini DM, Henson D, LaManca J, Levine S: Respiratory muscle function and dyspnea in patients with chronic congestive heart failure. Circulation 1992;86:909-918.

23 Wilson JR, Mancini DM: The mechanism of extertional fatigue in heart failure. Cardioscience 1990;1:13-17.

24 Engelen MP, Schols AM, Wouters EF: Nutritional depletion in relation to respiratory and peripheral skeletal muscle function in out-patients with COPD. Eur Respir J 1994;7:17931797.

25 Whittom F, Jobin J, Simard PM, Leblanc P, Simard C, Bernard S, Belleau R, Maltais F: Histochemical and morphological characteristics of the vastus lateralis muscle in patients with chronic obstructive pulmonary disease. Med Sci Sports Exerc 1998;30:1467-1474.

26 Rochester DF: Body weight and respiratory muscle function in chronic obstructive pulmonary disease. Am Rev Respir Dis 1986;134: 646-648.

27 Sato Y, Asoh T, Honda Y, Fujimatsu Y, Higuchi I, Oizumi K: Morphologic and histochemical evaluation of muscle in patients with chronic pulmonary emphysema manifesting generalized emaciation. Eur Neurol 1997;37: 116-121.

28 Gosker HR, Engelen MPKJ, Mameren van H, Dijk van PJ, Vusse van der GJ, Wouters EFM, Schols AMWJ: Muscle fibre type IIX atrophy is involved in the loss of fat-free mass in chronic obstructive pulmonary disease. Am J Clin Nutr 2001; in press.

29 Vescovo G, Volterrani M, Zennaro R, Sandri M, Ceconi C, Lorusso R, Ferrari R, Ambrosio GB, Dalla Libera L: Apoptosis in skeletal muscle of patients with heart failure: Investigation of clinical and biochemical changes. Heart 2000;84:431-437.
30 Gertz I, Hedenstierna G, Hellers G, Wahren J: Muscle metabolism in patients with chronic obstructive lung disease and acute respiratory failure. Clin Sci Mol Med 1977;52:395-403.

31 Dunnigan A, Staley NA, Smith SA, Pierpont ME, Judd D, Benditt DG, Benson DW Jr: Cardiac and skeletal muscle abnormalities in cardiomyopathy: Comparison of patients with ventricular tachycardia or congestive heart failure. J Am Coll Cardiol 1987;10:608-618.

32 Lipkin DP, Jones DA, Roud JM, Poole Wilson PA: Abnormalities of skeletal muscle in patients with chronic heart failure. Int J Cardiol 1988;18:187-195.

33 Sullivan MJ, Green HJ, Cobb FR: Skeletal muscle biochemistry and histology in ambulatory patients with long-term heart failure. Circulation 1990;81:518-527.

34 Mancini DM, Coyle E, Coggan A, Beltz J, Ferraro N, Montain S, Wilson JR: Contribution of intrinsic skeletal muscle changes to ${ }^{31} \mathrm{P}$ NMR skeletal muscle metabolic abnormalities in patients with chronic heart failure. Circulation 1989;80:1338-1346.

35 Drexler H, Riede U, Münzel T, König H, Funke E, Just H: Alterations of skeletal muscle in chronic heart failure. Circulation 1992;85: 1751-1759.

36 Lampert E, Mettauer B, Hoppeler H, Charloux A, Charpentier A, Lonsdorfer J: Structure of skeletal muscle in heart transplant recipients. J Am Coll Cardiol 1996;28:980-984.

37 Hambrecht R, Fiehn E, Yu J, Niebauer J, Weigl C, Hilbrich L, Adams V, Riede U, Schuler G: Effects of endurance training on mitochondrial ultrastructure and fiber type distribution in skeletal muscle of patients with stable chronic heart failure. J Am Coll Cardiol 1997; 29:1067-1073.

38 McComas AJ: Skeletal Muscle: Form and Function. Champaign, Human Kinetics, 1996.

39 Schiaffino S, Reggiani C: Molecular diversity of myofibrillar proteins: Gene regulation and functional significance. Physiol Rev 1996;76: 371-423.

40 Pereira Sant'Ana JA, Ennion S, Sargeant AJ, Moorman AF, Goldspink G, Sant'ana Pereira J, Young A: Comparison of the molecular, antigenic and ATPase determinants of fast myosin heavy chains in rat and human: A single-fibre study. Pflügers Arch 1997;435:151-163.

41 Satta A, Migliori GB, Spanevello A, Neri M, Bottinelli R, Canepari M, Pellegrino MA, Reggiani $\mathrm{C}$ : Fibre types in skeletal muscles of chronic obstructive pulmonary disease patients related to respiratory function and exercise tolerance. Eur Respir J 1997;10:2853-2860.

42 Hildebrand IL, Sylvén C, Esbjörnsson M, Hellström K, Jansson E: Does chronic hypoxaemia induce transformations of fibre types? Acta Physiol Scand 1991;141:435-439.

43 Sullivan MJ, Duscha BD, Klitgaard H, Kraus WE, Cobb FR, Saltin B: Altered expression of myosin heavy chain in human skeletal muscle in chronic heart failure. Med Sci Sports Exerc 1997;29:860-866. 
44 Gosker HR, Mameren H, Schols, AMWJ: Fiber type redistribution in limb muscle in COPD occurs through gradual changes in myosin isoform content. Eur Respir J 2000; 16(suppl 31):p559s

45 Harridge SD, Magnusson G, Gordon A: Skeletal muscle contractile characteristics and fatigue resistance in patients with chronic heart failure. Eur Heart J 1996;17:896-901.

46 Pouw EM, Schold AMWJ, Wouters EFM: Elevated inosine monophosphate levels in resting muscle of patients with stable COPD. Am J Respir Crit Care Med 1998;157:453-457.

47 Dudley GA, Terjung RL: Influence of aerobic metabolism on IMP accumulation in fasttwitch muscle. Am J Physiol 1985;248:C3742.

48 Thompson CH, Davies RJ, Kemp GJ, Taylor DJ, Radda GK, Rajagopalan B: Skeletal muscle metabolism during exercise and recovery in patients with respiratory failure. Thorax 1993; 48:486-490.

49 Payen JF, Wuyam B, Levy P, Reutenauer H, Stieglitz P, Paramelle B, Le Baw JF: Muscular metabolism during oxygen supplementation in patients with chronic hypoxemia. Am Rev Respir Dis 1993;147:592-598.

50 Mancini DM, Walter G, Reichek N, Lenkinski R, McCully KK, Mullen JL, Wilson JR: Contribution of skeletal muscle atrophy to exercise intolerance and altered muscle metabolism in heart failure. Circulation 1992;85:1364-1373.

51 Kemp GJ, Thompson CH, Stratton JR, Brunotte F, Conway M, Adamopoulos S, Arnolda L, Radda GK, Rajagopalan B: Abnormalities in exercising skeletal muscle in congestive heart failure can be explained in terms of decreased mitochondrial ATP synthesis, reduced metabolic efficiency, and increased glycogenolysis. Heart 1996;76:35-41.

52 Stratton JR, Kemp GJ, Daly RC, Yacoub M, Rajagopalan B: Effects of cardiac transplantation on bioenergetic abnormalities of skeletal muscle in congestive heart failure. Circulation 1994;89:1624-1631.

53 Wuyam B, Payen JF, Levy P, Bensaidane H, Reutenauer H, Le Bas JF, Benabid AL: Metabolism and aerobic capacity of skeletal muscle in chronic respiratory failure related to chronic obstructive pulmonary disease. Eur Respir J 1992;5:157-162.

54 Thompson CH, Davies RJ, Kemp GJ, Taylor DJ, Radda GK, Rajagopalan B: Skeletal muscle metabolism during exercise and recovery in patients with respiratory failure. Thorax 1993 ; 48:486-490.

55 Payen JF, Wuyam B, Levy P, Reutenauer H, Stieglitz P, Paramelle B, Le Bas JF: Muscular metabolism during oxygen supplementation in patients with chronic hypoxemia. Am Rev Respir Dis 1993;147:592-598.

56 Evans AB, al-Himyary AJ, Hrovat MI, Pappagianopoulos P, Wain JC, Ginns LC, Systrom DM: Abnormal skeletal muscle oxidative capacity after lung transplantation by ${ }^{31} \mathrm{P}-\mathrm{MRS}$. Am J Respir Crit Care Med 1997;155:615621.
57 Tata H, Kato H, Misawa T, Sasaki F, Hayashi S, Takahashi H, Kutsumi Y, Ishizaki T, Nakai $\mathrm{T}$, Miyabo S: ${ }^{31} \mathrm{P}$-nuclear magnetic resonance evidence of abnormal skeletal muscle metabolism in patients with chronic lung disease and congestive heart failure. Eur Respir J 1992;5: 163-169.

58 Kutsuzawa T, Shioya S, Kurita D, Haida M, Ohta Y, Yamabayashi H: ${ }^{31} \mathrm{P}-\mathrm{NMR}$ study of skeletal muscle metabolism in patients with chronic respiratory impairment. Am Rev Respir Dis 1992;146:1019-1024.

59 Okita K, Yonezawa K, Nishijima H, Hanada A, Ohtsubo M, Kohya T, Murakami T, Kitabatake A: Skeletal muscle metabolism limits exercise capacity in patients with chronic heart failure. Circulation 1998;98:1886-1891.

60 Chati Z, Zannad F, Jeandel C, Lherbier B, Escanye JM, Robert J, Aliot E: Physical deconditioning may be a mechanism for the skeletal muscle energy phosphate metabolism abnormalities in chronic heart failure. Am Heart J 1996;13:560-566.

61 Mancini DM, Ferraro N, Tuchler M, Chance B, Wilson JR: Detection of abnormal calf muscle metabolism in patients with heart failure using phosphorus-31 nuclear magnetic resonance. Am J Cardiol 1988;62:1234-1240.

62 Essén-Gustavsson B, Henriksson J: Enzyme levels in pools of microdissected human muscle fibres of identified type: Adaptive response to exercise. Acta Physiol Scand 1984;120:505515.

63 Hoppeler H, Desplanches D: Muscle structural modifications in hypoxia. Int $\mathrm{J}$ Sports Med 1992;13:S166-S168.

64 Howald H, Pette D, Simoneau JA, Uber A, Hoppeler H, Cerretelli P: Effects of chronic hypoxia on muscle enzyme activities. Int $\mathrm{J}$ Sports Med 1990;11:S10-S14.

65 Melissa L, MacDougall JD, Tarnopolsky MA, Cipriano N, Green HJ: Skeletal muscle adaptations to training under normobaric hypoxic versus normoxic conditions. Med Sci Sports Exerc 1997;29:238-243.

66 Bigard AX, Brunet A, Guezennec CY, Monod $\mathrm{H}$ : Effects of chronic hypoxia and endurance training on muscle capillarity in rats. Pflügers Arch 1991;419:225-229.

67 Snyder G, Farrelly C, Coelho J: Adaptations in skeletal muscle capillarity following changes in oxygen supply and changes in oxygen demands. Eur J Appl Physiol 1992;65:158-163.

68 Preedy VR, Smith DM, Sugden PH: The effects of 6 hours of hypoxia on protein synthesis in rat tissues in vivo and in vitro. Biochem $\mathrm{J}$ 1985;228:179-185.

69 Kwast KE, Hand SC: Acute depression of mitochondrial protein synthesis during anoxia: Contributions of oxygen sensing, matrix acidification, and redox state. J Biol Chem 1996;271: 7313-7319.
70 Ishihara A, Itoh K, Oishi Y, Itoh M, Hirofuji C, Hayashi $\mathrm{H}$ : Effects of hypobaric hypoxia on histochemical fibre-type composition and myosin heavy chain isoform component in the rat soleus muscle. Pflügers Arch 1995;429:601606.

71 Pastoris O, Dossena M, Foppa P, Arnaboldi R Giorini A, Villa RF, Benzi G: Modifications by chronic intermittent hypoxia and drug treatment on skeletal muscle metabolism. Neurochem Res 1995;20:143-150.

72 Pastoris O, Gorini A, Vercesi L, Taglietti M, Dossena M: Modification of the skeletal muscle energy metabolism induced by intermittent normobaric hypoxia and treatment with biological pyrimidines. Farmaco Sci 1985;40:442_ 453.

73 Takahashi H, Kikuchi K, Nakayama H: Effect of chronic hypoxia on oxidative enzyme activity in rat skeletal muscle. Ann Physiol Anthropol 1993;12:363-369.

74 Cartee GD, Douen AG, Ramlal T, Klip A, Holloszy JO: Stimulation of glucose transport in skeletal muscle by hypoxia. J Appl Physiol 1991;70:1593-1600.

75 Xia Y, Warshaw JB, Haddad GG: Effect of chronic hypoxia on glucose transporters in heart and skeletal muscle of immature and adult rats. Am J Physiol 1997;273:R17341741

76 Rahman I, Morrison D, Donaldson K, MacNee $\mathrm{W}$ : Systemic oxidative stress in asthma, COPD, and smokers. Am J Respir Crit Care Med 1996;154:1055-1060.

77 Keith M, Geranmayegan A, Sole MJ, Kurian $\mathrm{R}$, Robinson A, Omran AS, Jeejeebhoy $\mathrm{KN}$ : Increased oxidative stress in patients with congestive heart failure. J Am Coll Cardiol 1998; 31:1352-1358

78 Giuliani A, Cestaro B: Exercise, free radical generation and vitamins. Eur J Cancer Prevention 1997;6:S55-67.

79 Ji LL: Exercise, oxidative stress, and antioxidants. Am J Sports Med 1996;24:S20-24.

80 Reid MB: Reactive oxygen and nitric oxide in skeletal muscle. News Physiol Sci 1996;11: 114-119.

81 Buck M, Chojkier M: Muscle wasting and dedifferentiation induced by oxidative stress in a murine model of cachexia is prevented by inhibitors of nitric oxide synthesis and antioxidants. EMBO J 1996;15:1753-1765.

82 de Godoy I, Donahoe M, Calhoun WJ, Mancino J, Rogers RM: Elevated TNF-alpha production by peripheral blood monocytes of weightlosing COPD patients. Am J Respir Crit Care Med 1996;153:633-637.

83 Schols AM, Buurman WA, Staal van den Brekel AJ, Dentener MA, Wouters EF: Evidence for a relation between metabolic derangements and increased levels of inflammatory mediators in a subgroup of patients with chronic obstructive pulmonary disease. Thorax 1996; 51:819-824.

84 Levine B, Kalman J, Mayer L, Fillit HM, Packer M: Elevated circulating levels of tumor necrosis factor in severe chronic heart failure. $\mathrm{N}$ Engl J Med 1990;323:236-241. 
85 Anker SD, Clark AL, Kemp M, Salsbury C, Teixeira MM, Hellewell PG, Coats AJ: Tumor necrosis factor and steroid metabolism in chronic heart failure: Possible relation to muscle wasting. J Am Coll Cardiol 1997;30:9071001.

86 Clarkson P: Antioxidants and physical performance. Crit Rev Food Sci Nutr 1995;35:131141.

87 Ferrari R, Ceconi C, Curello S, Alfieri O, Visioli O: Myocardial damage during ischaemia and reperfusion. Eur Heart J 1993;14:25-30.

88 Liu J, Simon LM, Phillips JR, Robin ED: Superoxide dismutase (SOD) activity in hypoxic mammalian systems. J Appl Physiol 1977; 42:107-110.

89 Li RK, Mickle DA, Weisel RD, Kemp M, Salsbury C, Teixeira MM, Hellewell PG, Coats AJ: Effect of oxygen tension on the anti-oxidant enzyme activities of tetralogy of Fallot ventricular myocytes. J Mol Cell Cardiol 1989;21: 567-575.

90 Smith DR, Stone D, Darley-Usmar VM: Stimulation of mitochondrial oxygen consumption in isolated cardiomyocytes after hypoxia-reoxygenation. Free Radic Res 1996;24:159-166.

91 Haramaki N, Packer L: Oxidative stress indices in exercise; in Sen KC, Packer L, Hänninen $\mathrm{O}$ (eds): Exercise and Oxygen Toxicity. Amsterdam, Elsevier Science, 1994, pp 77-87.

92 Stryer L: Biochemistry. New York, Freeman, 1988.

93 Xu KY, Zweier JL, Becker LC: Hydroxyl radical inhibits sarcoplasmic reticulum $\mathrm{Ca}^{2+}$ ATPase function by direct attack on the ATP binding site. Circ Res 1997;80:76-81.

94 Minezaki K, Suleiman M, Chapman R: Changes in mitochondrial function induced in isolated guinea-pig ventricular myocytes by calcium overload. J Physiol Lond 1994;476: 459-471.

95 Dean RT, Fu SL, Stocker R, Davies MJ: Biochemistry and pathology of radical-mediated protein oxidation. Biochem J 1997;324:1-18.

96 Nagasawa T, Hatayama T, Watanabe Y, Tanaka M, Niisato Y, Kitts DD: Free radical mediated effects on skeletal muscle protein in rats treated with fe nitrilotriacetate. Biochem Biophys Res Commun 1997;231:37-41.

97 Soares JM, Duarte JA, Carvalho J: The possible role of intracellular $\mathrm{Ca}^{2+}$ accumulation for the development of immobilization atrophy. Int J Sports Med 1993;14:437-439.

98 Thomas PK, Cooper JM, King RH, Workman JM, Schapira AH, Goss Sampson MA, Muller DP: Myopathy in vitamin E deficient rats: muscle fibre necrosis associated with disturbances of mitochondrial function. J Anat 1993; 183:451-461.

99 Haycock JW, Jones P, Harris JB: Differential susceptibility of human skeletal muscle proteins to free radical induced oxidative damage: A histochemical, immunocytochemical and electron microscopical study in vitro. Acta Neuropathol Berl 1996;92:331-340.
100 Stangel M, Zettl UK, Mix E, Zielasek J, Toyka KV, Hartung HP, Gold R: $\mathrm{H}_{2} \mathrm{O}_{2}$ and nitric oxide-mediated oxidative stress induce apoptosis in rat skeletal muscle myoblasts. J Neuropathol Exp Neurol 1996;55:36-43.

101 Berg HE, Tesch PA: Changes in muscle function in response to 10 days of lower limb unloading in humans. Acta Physiol Scand 1996; 157:63-70.

102 Terjung RL, Dudley GA, Meyer RA: Metabolic and circulatory limitations to muscular performance at the organ level. J Exp Biol 1985; 115:307-318.

103 Messner-Pellenc P, Brasileiro C, Ahmaidi S, Mercier J, Ximenes C, Grolleau R, Prefaut C: Exercise intolerance in patients with chronic heart failure: Role of pulmonary diffusing limitation. Eur Heart J 1995; 16:201-209.

104 Gray-Donald K, Gibbons L, Martin JG: Effect of nutritional status on exercise performance in patients with chronic obstructive pulmonary disease. Am Rev Respir Dis 1989; 140:1544-1548.

105 Efthimiou J, Fleming J, Gomes C, Spiro SG: The effect of supplementary oral nutrition in poorly nourished patients with chronic obstructive pulmonary disease. Am Rev Respir Dis 1988; 137:1075-1082.

106 Carr JG, Stevenson LW, Walden JA, Heber $\mathrm{D}$ : Prevalence and hemodynamic correlates of malnutrition in severe congestive heart failure secondary to ischemic or idiopathic dilated cardiomyopathy. Am J Cardiol 1989; 63:709-713.

107 Schols AMWJ, Slangen J, Volovics L, Wouters EMF: Weight loss is a reversible factor in the prognosis of chronic obstructive pulmonary disease. Am J Respir Crit Care Med 1998;157:1791-1797.

108 Anker SD, Ponikowski P, Varney S, Chua TP, Clark AL, Webb-People KM, Harrington D, Kox WJ, Poole-Wilson PA, Coats AJS: Wasting as independent risk factor for mortality in chronic heart failure. Lancet 1997;349:10501053 .

109 Schols AM, Soeters PB, Dingemans AM, Mostert R, Frantzen PJ, Wouters EF: Prevalence and characteristics of nutritional depletion in patients with stable COPD eligible for pulmonary rehabilitation. Am Rev Respir Dis 1993;147:1151-1156.

110 Baarends EM, Schols AM, Pannemans DL, Westerterp KR, Wouters EF: Total free living energy expenditure in patients with severe chronic obstructive pulmonary disease. Am J Respir Crit Care Med 1997;155:549-554.

111 McLoughlin DM, Spargo E, Wassif WS, Newham DJ, Peters TJ, Lantos PL, Russell GF: Structural and functional changes in skeletal muscle in anorexia nervosa. Acta Neuropathol Berl 1998;95:632-640.

112 Russel DM, Prendergast PJ, Darby PL, Garfinkel PE, Whitwell J, Jeejeebhoy KN: A comparison between muscle function and body composition in anorexia nervosa: The effect of refeeding. Am J Clin Nutr 1983;38:229_ 237.
113 Rigaud D, Moukaddem M, Cohen B, Malon D, Reveillard V, Mignon M: Refeeding improves muscle performance without normalization of muscle mass and oxygen consumption in anorexia nervosa patients. Am J Clin Nutr 1997;65:1845-1851.

114 Lindboe CF, Askevold F, Slettebo M: Changes in skeletal muscles of young women with anorexia nervosa: An enzyme histochemical study. Acta Neuropathol Berl 1982; 56:299-302.

115 Essen B, Fohlin L, Thoren C, Saltin B: Skeletal muscle fibre types and sizes in anorexia nervosa patients. Clin Physiol 1981;1:395403.

116 Hill GL: Body composition research: Implications for the practice of clinical nutrition. J Parenter Enteral Nutr 1992;16:197-218.

117 Morrison WL, Gibson JN, Scrimgeour C, Rennie MJ: Muscle wasting in emphysema. Clin Sci 1988;75:415-420.

118 Engelen MPKJ, Deutz NEP, Wouters EFM, Schols AMWJ: Enhanced whole body protein turnover in patients with chronic obstructive pulmonary disease. Am J Respir Crit Care Med 2000;162:1488-1492.

119 Aguilani B, Goldstein Shapses S, Pajon A, Levy P, Sarrot F, Leverve X, Page E, Askanazi J: Muscle protein degradation in severely malnourished patients with chronic obstructive pulmonary disease subject to short-term total parenteral nutrition. J Parenter Enteral Nutr 1992;16:248-254.

120 Goldstein SA, Thomashow BM, Kvetan V, Askanazi J, Kinney JM, Elwyn DH: Nitrogen and energy relationships in malnourished patients with emphysema. Am Rev Respir Dis 1988;138:636-644.

121 Engelen MPKJ, Deutz NEP, Wouters EFM, Mosterd R, Schols AMWJ: Suppressed response in whole body protein turnover to exercise in patients with emphysema; thesis, 2000.

122 Engelen MPKJ, Schols AMWJ, Does JD, Deutz NEP, Wouters EFM: Altered glutamate metabolism is associated with reduced muscle glutathione levels in patients with emphysema. Am J Respir Crit Care Med 2000; 161:98-103.

123 Engelen MPKJ, Wouters EFM, Deutz NEP, Does JD, Schols AMWJ: Effects of exercise on amino acid metabolism in patients with chronic obstructive pulmonary disease. Am J Respir Crit Care Med 2000;163:859-864.

124 Jakobsson P, Jorfeldt L, Brundin A: Skeletal muscle metabolites and fibre types in patients with advanced chronic obstructive pulmonary disease (COPD), with and withou chronic respiratory failure. Eur Respir J 1990; 3:192-196.

125 Hughes RL, Katz H, Sahgal V, Campbell JA, Hartz R, Shields TW: Fiber size and energy metabolites in five separate muscles from patients with chronic obstructive lung diseases. Respiration 1983;44:321-328. 
126 Fiaccadori E, Del Canale S, Vitali P, Coffrini E, Ronda N, Guariglia A: Skeletal muscle energetics, acid-base equilibrium and lactate metabolism in patients with severe hypercapnia and hypoxemia. Chest 1987;92:883-887.

127 Broqvist M, Arnqvist H, Dahlström U, Larsson J, Nylander E, Permert J: Nutritional assessment and muscle energy metabolism in severe chronic congestive heart failure - effects of long-term dietary supplementation. Eur Heart J 1994; 15:1641-1650.

128 Opasich C, Aquilani R, Dossena M, et al: Biochemical analysis of muscle biopsy in overnight fasting patients with severe chronic heart failure. Eur Heart J 1996;17:16861693.

129 Schaufelberger M, Eriksson BO, Held P, Swedberg K: Skeletal muscle metabolism during exercise in patients with chronic heart failure. Heart 1996;76:29-34.
130 Maltais F, Simard AA, Simard C, Jobin J, Desgagnes P, LeBlanc P: Oxidative capacity of the skeletal muscle and lactic acid kinetics during exercise in normal subjects and in patients with COPD. Am J Respir Crit Care Med 1996;153:288-293.

131 Jakobsson P, Jorfeldt L, Henriksson J: Metabolic enzyme activity in the quadriceps femoris muscle in patients with severe chronic obstructive pulmonary disease. Am J Respir Crit Care Med 1995;151:374-377.

132 Sullivan MJ, Green HJ, Cobb FR: Altered skeletal muscle metabolic response to exercise in chronic heart failure: Relation to skeletal muscle aerobic enzyme activity. Circulation 1991;84:1597-1607.
133 Tikunov B, Levine S, Mancini D: Chronic congestive heart failure elicits adaptations of endurance exercise in diaphragmatic muscle. Circulation 1997;95:910-916.

134 Sánchez J, Bastien C, Medrano G, Riquet M, Derenne JP: Metabolic enzymatic activities in the diaphragm of normal men and patients with moderate chronic obstructive pulmonary disease. Bull Eur Physiopathol Respir 1984;20:535-540.

A.M.W.J. Schols

Department of Pulmonology

University Hospital Maastricht

PO Box 5800

NL-6202 AZ Maastricht (The Netherlands)

Tel. +31 43 3875046, Fax +31 433875051

E-Mail a.schols@pul.unimaas.nl 